\title{
PEMANFAATAN MEDIA PEMBELAJARAN VIDEOSCRIBE SEBAGAI ALTERNATIF PEMBELAJARAN DARING BAHASA INDONESIA DI SMKN 1 CANGKRINGAN
}

\author{
YUNIASIH \\ SMKN 1 Cangkringan, Sleman \\ e-mail: yunismkn81@gamil.com
}

\begin{abstract}
ABSTRAK
Interaksi dalam pembelajaran daring sangat terbatas sehingga pendidik harus bisa kreatif dan inovatif memilih media pembelajaran, khususnya dalam mata pelajaran Bahasa Indonesia agar dapat meningkatkan hasil belajar peserta didik di rumah. Penerapan media pembelajaran videoscribe dalam pembelajaran daring Bahasa Indonesia merupakan salah satu pemanfaatan teknologi media pembelajaran berbasis animasi yang sesuai dengan perkembangan zaman sehingga diharapkan dapat meningkatkan mutu pendidikan. Tujuan best practice ini adalah untuk mendeskripsikan pemanfaat media pembelajaran videoscribe sebagai alternatif pembelajaran daring Bahasa Indonesia kelas XI di SMKN 1 Cangkringan. Praktik terbaik dilakukan pada bulan November, Semester Ganjil Tahun Ajaran 2020/2021 dengan subyek penelitian sejumlah 66 siswa. Tujuan karya tulis ilmiah ini untuk mendeskripsikan peningkatan hasil belajar dengan memanfaatkan teknologi media pembelajaran videoscribe sebagai alternatif media pembelajaran daring pada mata pelajaran Bahasa Indonesia. Penerapan media pembelajaran videoscribe dapat meningkatkan hasil belajar daring yaitu (1) hasil belajar daring KD pengetahuan mengalami peningkatan sebesar $24,42 \%$, sedangkan peningkatan hasil belajar daring KD keterampilan sebesar 23,47\%. Selain itu, tingkat ketuntasan peserta didik mengalami peningkatan. Peningkatan ketuntasan peserta didik KD pengetahuan sebesar 37,36\%, sedangkan peningkatan ketuntasan peserta didik KD keterampilan sebesar 53,59\%.
\end{abstract}

Kata Kunci: Media VideoScribe, Pembelajaran Daring, Antologi Cerpen

\section{ABSTRACT}

Interaction in online learning is very limited so educators must be creative and innovative in choosing learning media, especially in Indonesian subjects in order to improve student learning outcomes at home. The application of videoscribe learning media in Indonesian online learning is one of the uses of animation-based learning media technology that is in accordance with the times so that it is expected to improve the quality of education. The purpose of this best practice is to describe the use of the videoscribe learning media as an alternative to online learning Indonesian class XI at SMKN 1 Cangkringan. The best practice was carried out in November, Odd Semester of the 2020/2021 Academic Year with 66 students as research subjects. The purpose of this scientific paper is to describe the improvement of learning outcomes by utilizing videoscribe learning media technology as an alternative online learning media in Indonesian subjects. The application of videoscribe learning media can improve online learning outcomes, namely (1) online learning outcomes for knowledge KD have increased by $24.42 \%$, while online learning outcomes for skills KD have increased by $23.47 \%$. In addition, the level of completeness of students has increased. The increase in mastery of KD knowledge students is $37.36 \%$, while the increase in mastery of KD skills students is $53.59 \%$.

Keywords: VideoScribe Media, Online Learning, Short Story Anthology

\section{PENDAHULUAN}

Pembelajaran dalam jaringan (daring) atau yang lebih dikenal oleh masyarakat online yang dilaksanakan sejak bulan Maret 2020 sesuai dengan Surat Edaran Nomor 4 Tahun 2020 tentang Pelaksanaan Pendidikan Dalam Masa Darurat Coronavirus Disease (Covid-19) memberikan pengalaman baru bagi pendidik maupun peserta didik. Pembelajaran daring pada umumnya dilakukan melalui grup wathsap dan googel classroom. Dengan begitu, interaksi 


\section{LANGUAGE : Jurnal Inovasi Pendidikan Bahasa dan Sastra Vol 2. No 1. Februari 2022, e-ISSN : 2807-1670 | p-ISSN : 2807-2316}

dalam pembelajaran daring sangat terbatas sehingga pendidik harus bisa memilih media pembelajaran yang sesuai, khususnya dalam mata pelajaran Bahasa Indonesia agar dapat meningkatkan hasil belajar peserta didik di rumah.

Hal tersebut, sesuai dengan pendapat Wina Sanjaya (2008), yang mengatakan bahwa faktor yang mempengaruhi hasil belajar salah satunya adalah media pembelajaran. Oleh sebab itu, pendidik memilih menggunakan media pembelajaran untuk meningkatkan hasil belajar siswa dalam pembelajaran Bahasa Indonesia di kelas XI SMKN 1 Cangkringan. Media pembelajaran yang dapat digunakan dalam pembelajaran bermacam-macam. Menurut Samiharsono dan Hasanah (2017) media pembelajaran terdiri atas (1) alat bantu lihat, (2) alat bantu dengar, dan (3) alat bantu lihat-dengar. Alat atau media bantu lihat-dengar yang dapat membatu menstimulasi indera penglihatan dan indra pendengaran, misalnya televisi dan video.

Pembelajaran daring memerlukan media yang menarik. Media pembelajaran yang dipilih dapat memanfaatkan teknologi komputer berbasis video animasi yang di dalamnya bisa dipadukan antara animasi, grafis, ilustrasi, musik, dan suara penjelasan tentang materi yang diajarkan. Media seperti itu, misalnya videoscribe yang dikembangkan melalui aplikasi Sparkol VideoScribe.

Videoscribe menurut Oktavianingrum (2016), adalah software yang bisa digunakan dalam membuat desain animasi dengan layar putih yang sangat mudah dan menarik. Videoscribe dapat digunakan untuk penyajian informasi serta meningkatkan efektifitas pembelajaran. Pendidik dapat berkreasi melalui videoscribe sesuai dengan materi pembelajaran yang akan disampaikan dan situasi kondisi peserta didik sehingga diharapkan media yang digunakan dapat mempermudah dalam penyampaian materi pembelajaran dan diharapkan dapat meningkatkan hasil belajar peserta didik.

Hasil belajar menurut Dimyati (1999) dapat dipandang dari dua sisi, yaitu guru dan siswa. Bagi siswa, hasil belajar berarti tingkat perubahan perkembangan mental pada tiga ranah, yaitu kognitif, afektif, dan psikomotor. Hasil belajar yang dimiliki setiap peserta didik berbedabeda. Hasil belajar peserta didik sesuai dengan tingkat penguasaan materi pelajaran dinyatakan dalam bentuk nilai atau raport di setiap bidang studi setelah mengalami proses belajar mengajar. Hasil belajar pada mata pelajaran Bahasa Indonesia merupakan hasil yang telah dicapai oleh peserta didik setelah melakukan kegiatan belajar. Hasil ini dapat dilihat dari evaluasi yang merupakan nilai yang menunjukkan keberhasilan siswa dalam memahami setiap kompetensi dasar Bahasa Indonesia.

Untuk mata pelajaran Bahasa Indonesia di jenjang SMK menurut Permendikbud Tahun 2016 Nomor 024 Lampiran 03 materi SMK 2013, kompetensi yang harus dicapai peserta didik diantaranya adalah kompetensi pengetahuan dan kompetensi keterampilan. Setiap kompetensi dijabarkan ke dalam kompetensi dasar yang lebih rinci. Di Kelas XI pada mata pelajaran Bahasa Indonesia terdiri atas 20 kompetensi dasar. Hasil belajar kompetensi dasar inilah yang menjadi tolak ukur kemampuan peserta didik dalam menguasai mata pelajaran Bahasa Indonesia.

Kompetensi dasar tersebut salah satunya adalah kompetensi dasar pengetahuan 3.8. Mengidentifikasi nilai-nilai kehidupan dalam kumpulan cerita pendek dan kompetensi dasar keterampilan 4.8. Mendemonstrasikan salah satu nilai kehidupan yang dipelajari dalam cerita pendek. Kompetensi dasar tersebut diajarkan di semester gasal. Pembelajaran daring mata pelajaran Bahasa Indonesia pada semester gasal tahun 2020 di SMKN 1 Cangkringan banyak mengalami kendala. Maka dari itu, pendidik mencoba memanfaatkan media pembelajaran video berbasis animasi atau videoscribe untuk meningkatkan hasil belajar daring peserta didik di rumah.

Beberapa penelitian terdahulu yang pernah dilakukan oleh Setyowati, Pipin (2018) dari hasil analisis data menunjukkan bahwa nilai signifikansi uji $t_{\text {test }}$ sebesar $0,001<0,05$ terdapat pengaruh signiknifikan pembelajaran menggunakan metode discovery learning dan videoscribe terhadap hasil belajar mata pelajaran Simulasi Digital pada peserta didik kelas X di SMK Perwari. Peneltian yang lain dilakukan oleh Hudahana, Winda Dwi dan Sulaeman, Agus (2019) Pada perolehan hasil belajar keterampilan menulis cerita pendek berbasis pendidikan karakter 


\section{LANGUAGE : Jurnal Inovasi Pendidikan Bahasa dan Sastra Vol 2. No 1. Februari 2022, e-ISSN : 2807-1670 | p-ISSN : 2807-2316}

siswa kelas X di SMA N 1 Kabupaten Tangerang pada pretest yaitu rata-rata 61,5 meningkat menjadi rata-rata73,5 pada posttest. Hasil belajar keterampilan menulis cerita pendek berbasis pendidikan karakter siswa kelas X di SMA N 19 Kabupaten Tangerang pada pretest mendapat rata-rata 60 meningkat menjadi rata-rata 70 pada postest. Hasil belajar keterampilan menulis cerita pendek berbasis pendidikan karakter siswa kelas X di SMA Mandiri Balaraja Kabupaten Tangerang pada pretest yaitu rata-rata 61 meningkat menjadi rata-rata 68,5 pada postest. Disimpulkan bahwa media videoscribe efektif digunakan karena menarik minat siswa, siswa menjadi aktif, imajiansi, dan meningkatkan kreatifitas siswa.

Berdasarkan uraian tersebut, videoscribe dipilih sebagai solusi untuk meningkatkan hasil belajar peserta didik kelas XI pada mata pelajaran Bahasa Indonesia di SMKN 1 Cangkringan. Videoscribe digunakan sebagai media pembelajaran bahasa Indonesia di SMKN 1 Cangkringan dengan cara di unggah di youtube sehingga para peserta didik dapat dengan mudah melihat media tersebut menggunakan smartphone kapan saja dan di mana saja. Peserta didik juga dapat mendownload media videoscribe tersebut sehingga bisa mengamati berkalikali hingga benar-benar memahami materi kompetensi dasar yang disampaikan.

Penggunaan videosbcribe pada mata pelajaran Bahasa Indonesia telah dipraktikan pada bulan November, Semester Ganjil Tahun Ajaran 2020/2021 dengan subyek penelitian sejumlah 66 peserta didik. Berdasarkan hasil penelitian di kelas XI APL1, APHP4 didapatkan: (1) hasil belajar daring KD pengetahuan mengalami peningkatan sebesar 24,42\%, sedangkan peningkatan hasil belajar daring KD keterampilan sebesar $23,47 \%$. Selain itu, tingkat ketuntasan peserta didik mengalami peningkatan. Peningkatan ketuntasan peserta didik KD pengetahuan sebesar 37,36\%, sedangkan peningkatan ketuntasan peserta didik KD keterampilan adalah 53,59\%.

\section{METODE PENELITIAN}

Pemanfaatan videoscribe sebagai alternatif dalam pembelajaran daring Bahasa Indonesia dipilih oleh penulis sebagai best practice pada masa pembelajaran daring covid-19 karena dapat meningkatkan motivasi dan hasil belajar peserta didik. Data yang digunakan dalam best practice ini adalah data-data dari pelaksanaan pembelajaran Bahasa Indonesia. Datadata tersebut berupa hasil dokumentasi proses pembuatan videoscribe $\mathrm{KD} 3.8$ dan KD 4.8, videoscribe, proses penggunaan videoscribe dalam pembelajaran, absensi, daftar nilai, respons peserta didik, dan lain-lain.

Best practice dilaksanakan di kelas XI yang peneliti ajar, yaitu kelas XI APL1, APHP4, dengan peserta didik berjumlah 66 pada tanggal 1-15 November semester Gasal tahun ajaran 2020/2021. Tempat pelaksanaan best practice adalah SMK Negeri 1 Cangkringan yang beralamatkan di Sintokan, Wukirsari, Cangkringan, Sleman. Bahan yang digunakan dalam best practice adalah videoscribe kompetensi dasar pengetahuan 3.8. Mengidentifikasi nilai-nilai kehidupan dalam kumpulan cerita pendek dan kompetensi dasar keterampilan 4.8. Mendemonstrasikan salah satu nilai kehidupan yang dipelajari dalam cerita pendek. Videoscribe ini dibuat dengan memanfaatkan teknologi media pembelajaran aplikasi Sparkol VideoScribe.

Teknik pengumpulan data best practice adalah menganalisis dan mengkaji dokumentasi (a) proses penerapan media videoscribe dalam pembelajaran Bahasa Indonesia dan (b) hasil pembelajaran daring KD pengetahuan, yaitu 3.8. Mengidentifikasi nilai-nilai kehidupan yang terkandung dalam kumpulan cerita pendek yang dibaca dan KD keterampilan 4.8. Mendemonstrasikan salah satu nilai kehidupan yang dipelajari dalam cerita pendek. Secara rinci, langkah-langkah best practise sebagai berikut.

1) Menganalisis hasil pembelajaran daring Bahasa Indonesia yang menurun, ditandai dengan banyaknya peserta didik yang tidak tuntas.

2) Menentukan hal yang akan digunakan oleh pendidik untuk meningkatkan hasil belajar daring. Sesuai kondisi kompetensi dasar yang belum diajarkan atau melanjutkan kompetensi dasar yang telah diajarkan. 
3) Pendidik menentukan untuk meningkatkan hasil belajar daring menggunakan media pembelajaran videoscribe karena media tersebut dinilai dapat menjembatani antara pendidik dan peserta didik dalam proses belajar Bahasa Indonesia.

4) Selanjutnya, membuat Rencana Pelaksanaan Pembelajaran (RPP) dengan menggunakan videoscribe.

5) Pendidik membuat media pembelajaran videoscribe sesuai dengan langkah-langkah yang telah ditentukan.

6) Pelaksanaan pembelajaran daring melalui whatshap (WA) grup pemebelajaran Bahasa Indonesia dan googel classroom (GC) Bahasa Indonesia kelas XI APL 1 dan XI APHP4.

7) Melakukan penilaian hasil belajar daring KD 3.8. dan 4.8.

8) Melakukan evaluasi secara menyeluruh terhadap hasil belajar peserta didik dalam pembelajaran daring menggunakan media videoscribe.

Dari hasil pelaksanaan pembelajaran daring Bahasa Indonesia menggunakan media pembelajaran videoscribe dibandingkan dengan hasil pembelajaran Bahasa Indonesia tanpa media pembelajaran videoscribe. Hasil perbandingkan tersebut kemudian dideskripsikan menjadi simpulan hasil best practice. Hasil best practice disajikan dalam bentuk tabel dan Gambar.

\section{HASIL DAN PEMBAHASAN}

\section{Hasil}

Pembelajaran daring Bahasa Indonesia di masa covid-19 yang dilakukan melalui grup wathsap, goggel classroom, dan zoom mengakibatkan interaksi antara pendidik dan peserta didik terbatas. Hal ini mengakibatkan pemahaman peserta didik menurun sehingga berpengaruh terhadap tingkat hasil belajar dan tingkat ketuntasan peserta didik. Maka dari itu, pendidik menggunakan media pembelajaran videoscribe untuk meningkatkan pemahaman peserta didik terhadap materi pembelajaran sehingga diharapkan dapat meningkatkan hasil belajar peserta didik. Hasil belajar daring Bahasa Indonesia dibagi menjadi dua, yaitu (1) hasil belajar kompetensi dasar pengetahuan dan hasil belajar kompetensi keterampilan.

Hasil belajar daring Bahasa Indonesia kompetensi dasar pengetahuan sebelum dan sesudah menggunakan videoscibe dapat dilihat pada Tabel 1 berikut.

Tabel 1. Hasil Belajar Daring Bahasa Indonesia Kompetensi Dasar Pengetahuan Sebelum dan Sesudah Menggunakan Media Videoscribe

\begin{tabular}{|l|l|l|l|l|l|l|l|l|}
\hline Indikator & KD 3.1 & $\begin{array}{l}\text { KD } \\
3.2\end{array}$ & KD 3.3 & KD 3.4 & KD 3.5 & $\begin{array}{l}\text { KD } \\
3.6\end{array}$ & KD 3.7 & KD 3.8 \\
\hline $\begin{array}{l}\text { Nilai } \\
\text { Tertinggi }\end{array}$ & 82 & 80 & 78 & 80 & 82 & 82 & 80 & 90 \\
\hline $\begin{array}{l}\text { Nilai } \\
\text { Terendah }\end{array}$ & 40 & 40 & 35 & 45 & 50 & 48 & 48 & 70 \\
\hline Rerata & 70,14 & 68,34 & 68,81 & 70,03 & 72,22 & 71,38 & 72,14 & 78,91 \\
\hline $\begin{array}{l}\text { Jumlah } \\
\text { siswa } \\
\text { Ketuntasan }\end{array}$ & 31 & 28 & 30 & 37 & 36 & 36 & 34 & 61 \\
\hline $\begin{array}{l}\text { Jumlah } \\
\text { Siswa Tidak } \\
\text { Tuntas }\end{array}$ & 32 & 38 & 33 & 29 & 30 & 30 & 32 & 5 \\
\hline
\end{tabular}

Tabel tersebut menunjukan nilai tertinggi, nilai terendah, rerata nilai, jumlah peserta didik yang tuntas dan tidak tuntas pada hasil belajar daring Bahasa Indonesia kompetensi dasar pengetahuan. Hasil belajar daring Bahasa Indonesia kompetensi dasar (KD) pengetahuan sebelum penggunaan media videoscribe diperoleh dari nilai harian pada KD 3.1, 3.2, 3.3, 3.4, 3.5, 3.6, dan 3.7; sedangkan hasil belajar setelah penggunaan media videoscribe diperoleh dari 
nilai harian KD 3.8. Jadi dapat dikatakan bahwa (1) data hasil belajar daring Bahasa Indonesia sebelum penggunaan media videoscribe diperoleh dari jumlah rerata nilai harian KD 3.1 - KD 3.7, (2) data hasil belajar daring Bahasa Indonesia setelah penggunaan media videoscribe diperoleh dari nilai harian KD 3.8, (3) data nilai tertinggi dan terendah sebelum penggunaan media videoscribe diperoleh dari nilai tertinggi dan nilai terendah KD 3.1-3.7, sedangkan data nilai tertinggi dan terendah setelah penggunaan media videoscribe diperoleh dari nilai KD 3.8, (4) data jumlah siswa tuntas dan tidak tuntas sebelum penggunaan media videoscribe diperoleh dari rerata jumlah nilai siswa tuntas dan nilai tidak tuntas KD 3.1-3.7, sedangkan data jumalah siswa tuntas dan tidak tuntas setelah penggunaan media videoscribe diperoleh dari nilai KD 3.8.

Berdasarkan data pada Tabel 1 hasil belajar daring Bahasa Indonesia kompetensi dasar pengetahuan tersebut dapat di buat Gambar sebagai berikut.

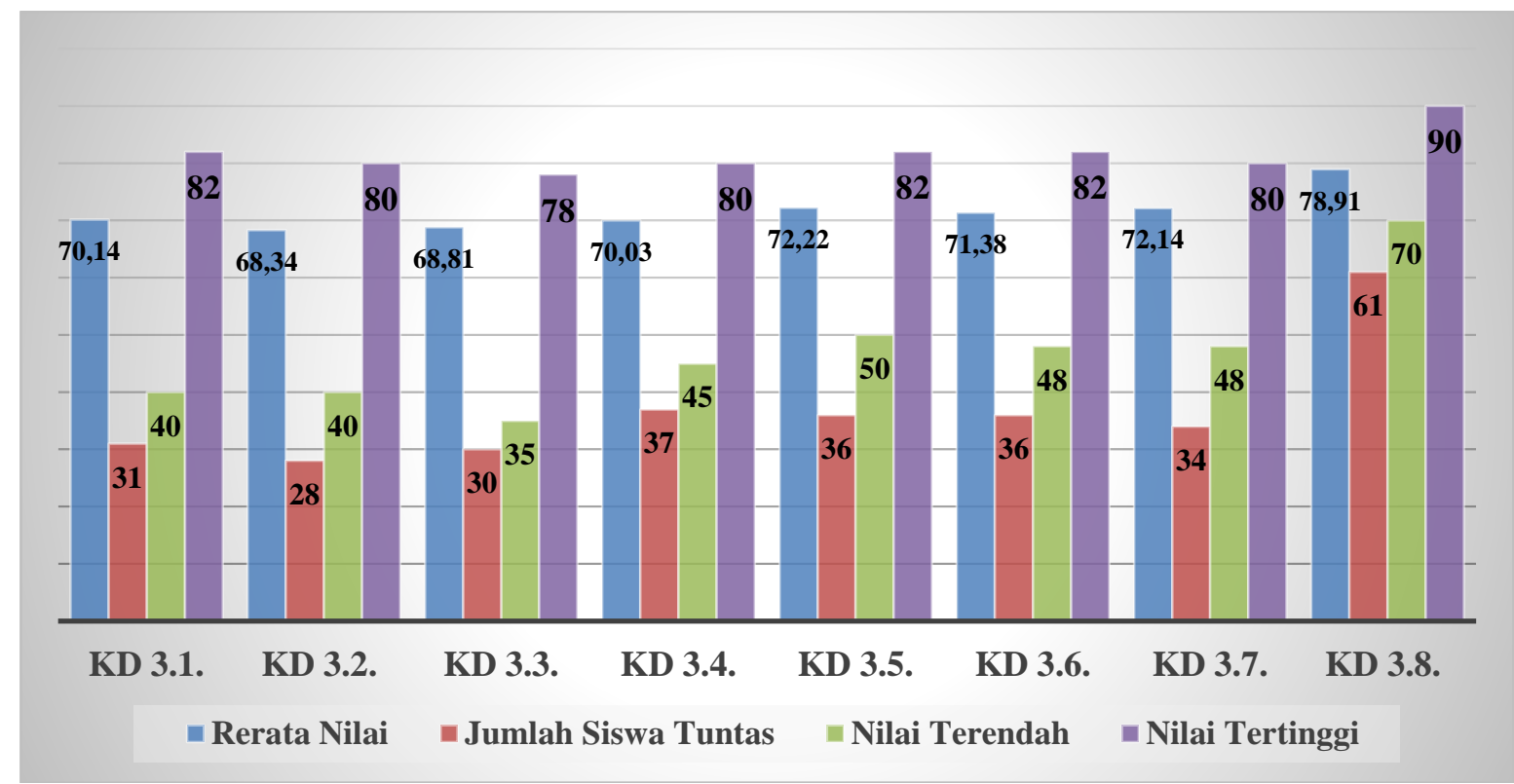

Gambar 1. Hasil Belajar Daring Bahasa Indonesia Kompetensi Pengetahuan Sebelum dan Sesudah Menggunakan Media Videoscribe

1 menggambarkan tingkat hasil belajar daring Bahasa Indonesia peserta didik sebelum dan setelah menggunakan media videoscribe. Gambar tersebut dapat dijelaskan bahwa Gambar batang yang berwarna biru menggambarkan rerata hasil belajar KD pengetahuan, Gambar batang warna merah menunjukan jumlah siswa tuntas, Gambar batang warna hijau menunjukan nilai terendah, dan Gambar batang warna ungu menunjukan nilai tertinggi.

Berdasarkan Tabel 1 dan Gambar 1 dapat dijelaskan bahwa rerata hasil belajar daring Bahasa Indonesia KD pengetahuan sebelum menggunakan videoscribe adalah KD 3.1: 70,14; KD 3.2: 68,34; KD 3.3: 68,81; KD 3.4: 70,03; KD 3.5: 72,22; KD 3.6: 71,38; dan KD 3.7: 72,14 ; sedangkan hasil belajar KD pengetahuan setelah penggunaan media videoscribe adalah KD 3.8: 79,9. Nilai tertinggi KD pengetahuan sebelum penggunaan media videoscribe adalah 82, sedangkan setelah penggunaan media videoscribe adalah 90. Nilai terendah KD pengetahuan sebelum menggunakan media videoscribe adalah 35 , sedangkan nilai terendah sebelum menggunakan media videoscribe adalah 70 . Jumlah peserta didik tuntas sebelum penggunaan media videoscribe pada tiap KD keterampilan adalah KD 3.1: 31; KD 3.2: 28; KD 3.3: 30; KD 3.4: 37; KD 3.5: 36; KD 3.6: 36; dan KD 3.7: 34; sedangkan jumlah peserta didik yang tuntas setelah penggunaan media videoscribe adalah KD 3.8: 61.

Hasil belajar daring Bahasa Indonesia kompetensi dasar keterampilan sebelum dan sesudah penggunaan Videoscribe dapat dilihat pada tabel berikut. 
LANGUAGE : Jurnal Inovasi Pendidikan Bahasa dan Sastra Vol 2. No 1. Februari 2022, e-ISSN : 2807-1670 | p-ISSN : 2807-2316

Tabel 2. Hasil Belajar Daring Bahasa Indonesia Kompetensi Dasar Keterampilan Sebelum dan Sesudah Penggunaan Media Videoscribe

\begin{tabular}{|l|l|l|l|l|l|l|l|l|}
\hline Indikator & KD 3.1 & $\begin{array}{l}\text { KD } \\
3.2\end{array}$ & KD 3.3 & KD 3.4 & KD 3.5 & $\begin{array}{l}\text { KD } \\
3.6\end{array}$ & KD 3.7 & KD 3.8 \\
\hline $\begin{array}{l}\text { Nilai } \\
\text { Tertinggi }\end{array}$ & 80 & 82 & 82 & 80 & 82 & 82 & 86 & 90 \\
\hline $\begin{array}{l}\text { Nilai } \\
\text { Terendah }\end{array}$ & 40 & 40 & 40 & 50 & 50 & 40 & 45 & 74 \\
\hline Rerata & 69,37 & 70,09 & 70,26 & 72,66 & 71,95 & 71,13 & 71,93 & 79,32 \\
\hline $\begin{array}{l}\text { Jumlah } \\
\text { siswa } \\
\text { Ketuntasan }\end{array}$ & 32 & 28 & 30 & 32 & 27 & 26 & 31 & 65 \\
\hline $\begin{array}{l}\text { Jumlah } \\
\text { Siswa Tidak } \\
\text { Tuntas }\end{array}$ & 34 & 38 & 36 & 34 & 39 & 40 & 35 & 1 \\
\hline
\end{tabular}

Tabel tersebut menunjukan nilai tertinggi, nilai terendah, rerata nilai, jumlah peserta didik yang tuntas dan tidak tuntas pada hasil belajar daring Bahasa Indonesia KD keterampilan. Berdasarkan data pada Tabel 2, dapat di buat Gambar sebagai berikut.

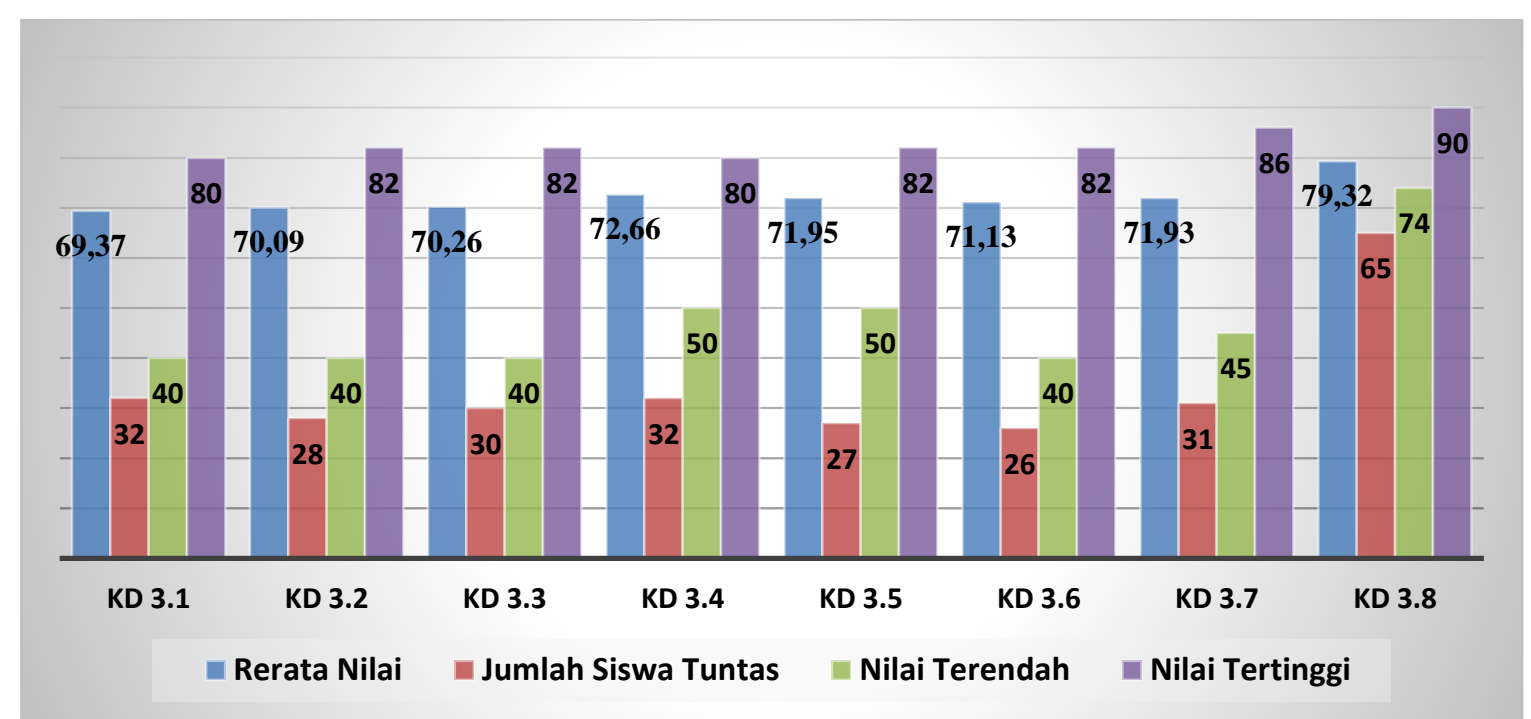

Gambar 2. Hasil Belajar Daring Bahasa Indonesia Kompetensi Keterampilan Sebelum dan Sesudah Menggunakan Media Videoscribe

Gambar 2 menggambarkan tingkat hasil belajar daring Bahasa Indonesia sebelum dan setelah penggunaan media pembelajaran videoscribe yang diperoleh peserta didik pada KD keterampilan. Gambar batang berwarna biru menggambarkan rerata hasil belajar. Gambar batang warna merah menunjukan jumlah siswa tuntas. Gambar batang warna hijau menunjukan nilai terendah. Gambar batang warna ungu menunjukan nilai tertinggi.

Berdasarkan Tabel 2 dan Gambar 2 dapat dijelaskan bahwa hasil belajar daring Bahasa Indonesia KD keterampilan sebelum menggunakan media videoscribe adalah KD 3.1: 69,37; KD 3.2: 70,09; KD 3.3: 70,26; KD 3.4: 72,66; KD 3.5: 71,95; KD 3.6: 71,13; dan KD 3.7: 71,93; sedangkan hasil belajar setelah menggunakan media videoscribe adalah KD 3.8: 79,32. Nilai tertinggi KD keterampilan sebelum penggunaan media videoscribe adalah 86, sedangkan setelah penggunaan media videoscribe adalah 90. Nilai terendah KD keterampilan sebelum menggunakan media videoscribe adalah 40, sedangkan nilai terendah sebelum menggunakan media videoscribe adalah 74 . Jumlah peserta didik tuntas sebelum penggunaan media videoscribe pada tiap KD keterampilan adalah KD 3.1: 32; KD 3.2: 28; KD 3.3: 30; KD 3.4: 
32; KD 3.5: 27; KD 3.6: 26; dan KD 3.7: 31; sedangkan jumlah peserta didik yang tuntas setelah penggunaan media videoscribe adalah KD 3.8: 65.

Kegiatan pelaksanaan pembelajaran menggunakan media videoscribe pada pembelajaran daring Bahasa Indonesia digambarkan pada Tabel 3 berikut.

Tabel 3. Penggunaan Media Pembelajaran Videoscribe dalam Pembelajaran Daring Bahasa Indonesia

\begin{tabular}{|c|c|c|c|c|c|c|}
\hline Kelas & $\begin{array}{c}\text { Hari, } \\
\text { Tanggal }\end{array}$ & $\begin{array}{c}\text { Kompetensi } \\
\text { Dasar }\end{array}$ & Materi & $\begin{array}{c}\text { Media } \\
\text { Penyampaian }\end{array}$ & $\begin{array}{l}\text { Bentuk } \\
\text { Tagihan }\end{array}$ & $\begin{array}{l}\text { Rerata } \\
\text { Nilai }\end{array}$ \\
\hline $\begin{array}{l}\text { XI } \\
\text { APL } 2\end{array}$ & $\begin{array}{c}\text { Senin, } 2 \\
\text { November } \\
2020\end{array}$ & KD 3.8 & $\begin{array}{c}\text { Nilai-Nilai } \\
\text { Kehidupan } \\
\text { dalam Antologi } \\
\text { Cerpen }\end{array}$ & $\begin{array}{c}\text { Grup WA, } \\
\text { Googel } \\
\text { Clasroom, } \\
\text { Youtube }\end{array}$ & $\begin{array}{l}\text { Pilihan } \\
\text { Ganda }\end{array}$ & 78,61 \\
\hline $\begin{array}{c}\text { XI } \\
\text { APL2 }\end{array}$ & $\begin{array}{c}\text { Jumat, } 6 \\
\text { November } \\
2020\end{array}$ & KD 4.8 & $\begin{array}{c}\text { Merencanakan } \\
\text { demonstrasi } \\
\text { salah satu nilai } \\
\text { kehidupan }\end{array}$ & $\begin{array}{c}\text { Grup WA, } \\
\text { Googel } \\
\text { Clasroom, } \\
\text { Youtube }\end{array}$ & $\begin{array}{l}\text { Tertulis, } \\
\text { Uraian }\end{array}$ & 79,24 \\
\hline $\begin{array}{c}\text { XI } \\
\text { APHP4 }\end{array}$ & $\begin{array}{c}\text { Selasa, } 3 \\
\text { November } \\
2020\end{array}$ & KD 3.8 & $\begin{array}{c}\text { Nilai-Nilai } \\
\text { Kehidupan } \\
\text { dalam Antologi } \\
\text { Cerpen }\end{array}$ & $\begin{array}{c}\text { Grup WA, } \\
\text { Googel } \\
\text { Clasroom, } \\
\text { Youtube }\end{array}$ & $\begin{array}{l}\text { Pilihan } \\
\text { Ganda }\end{array}$ & 79,2 \\
\hline $\begin{array}{c}\text { XI } \\
\text { APHP } \\
4\end{array}$ & $\begin{array}{c}\text { Rabu, } 4 \\
\text { November } \\
2020\end{array}$ & KD 4.8 & $\begin{array}{l}\text { Merencanakan } \\
\text { demonstrasi } \\
\text { salah satu nilai } \\
\text { kehidupan }\end{array}$ & $\begin{array}{c}\text { Grup WA, } \\
\text { Googel } \\
\text { Clasroom, } \\
\text { Youtube }\end{array}$ & $\begin{array}{l}\text { Tertulis, } \\
\text { Uraian }\end{array}$ & 79,4 \\
\hline
\end{tabular}

\section{Pembahasan}

Media pembelajaran adalah semua peralatan fisik yang disesain secara terencana untuk menyampaikan informasi dan membangun interaksi. Peralatan fisik yang dimaksudakan mencakup benda asli, bahan cetak, visual, audio, audio-visual, multimedia, dan web (Yaumi: 2018). Pendapat tersebut sejalan dengan pendapat Hasan (2001) yang mengatakan bahwa media adalah sarana untuk mentransfer atau menyampikan pesan, sedangkan media pembelajaran adalah media yang memuat informasi atau pesan instruksional dan dapat digunakan dalam proses pembelajaran. Dari dua pendapat tersebut dapat disimpulkan bahwa media pembelajaran adalah sarana atau peralatan berisi informasi instruksional yang didesain secara terencana untuk menyampaikan informasi dan membangun interaksi dalam proses pembelajaran.

Penyampaian dan interaksi pembelajaran terjadi antara pendidik dan peserta didik pada umumnya terjadi di dalam kelas. Akan tetapi sejak bulan Maret tahun 2020, wabah covid-19 melanda Indonesia sehingga pembelajaran dilakukan secara daring. Menurut K., R Gilang (2020) pembelajaran daring adalah pembelajaran yang menggunakan jaringan internet dengan aksesbilitas, konektivitas, dan fleksibilitas sehingga mampu memunculkan berbagai jenis interaksi pembelajaran. Interaksi pembelajaran daring Bahasa Indonesia terbatas dilakukan melalui grup WA, googel classroom, dan terkadang melalui zoom sehingga pemahaman peserta didik terhadap materi pembelajaran kurang. Hal tersebut dapat dilihat berdasarkan Tabel 4 dan Tabel 5 yang menyatakan bahwa (1) rerata hasil belajar kompetensi dasar pengetahuan adalah 70,50 dan peserta didik yang tuntas adalah 33 dari 66; sedangkan hasil belajar kompetensi dasar keterampilan adalah 71,11 dengan jumlah peserta didik tuntas 29 dari 66. Artinya, Rerata nilai hasil belajar kompetensi dasar pengetahuan dan keterampilan masih di bawah kriteria ketuntasan minimal (KKM) mata pelajaran Bahasa Indonesia, yaitu 75 dan hasil belajar peserta didik, baik kompetensi dasar pengetahuan maupun keterampilan hanya $50 \%$.

Menurut Pangondian (2019), pembelajaran daring agar berhasil, dipengaruhi tiga hal, yaitu (a) teknologi, (b) karakteristik pengajar, dan (c) karakteristik peserta didik. Pengajar atau 


\section{LANGUAGE : Jurnal Inovasi Pendidikan Bahasa dan Sastra Vol 2. No 1. Februari 2022, e-ISSN : 2807-1670 | p-ISSN : 2807-2316}

pendidik memiliki peran penting dalam menentukan efektifitas pembelajaran daring. Efektif tidaknya pembelajaran dapat diukur dari hasil belajar peserta didik. Hal tersebut sejalan dengan pendapat Matondang dkk (2019) yang mengatakan bahwa penilaian dan pengukuran hasil belajar siswa akan mempengaruhi langkah-langkah selanjutnya yang diambil seorang guru dalam mengembangkan kegiatan belajar mengajar. Dalam hal ini, Agar pembelajaran daring efektif, pendidik harus mampu memberikan materi atau penjelasan dan intruksi atau perintah kepada peserta didik secara jelas sehingga hasil belajar daring lebih baik. Kejelasan penyampaian materi dalam pembelajaran daring, salah satunya adalah media pembelajaran.

Pendapat tersebut sesuai dengan pendapat Sanjaya (2008) yang mengatakan bahwa "faktor yang mempengaruhi hasil belajar salah satunya adalah media pembelajaran". Hal tersebut juga senada dengan pendapat Sudjana dan Rivai (2013) yang mengatakan bahwa media pembelajaran dapat meningkatkan hasil belajar siswa, karena (1) pembelajaran akan lebih menarik sehingga menumbuhkan motivasi belajar, (2) materi pelajaran dapat disampaikan dengan lebih jelas sehingga siswa lebih memahami dan menguasai tujuan pembelajaran, (3) metode pengajaran lebih bervariasi, dan (4) siswa lebih banyak melakukan aktivitas belajar.

Media pembelajaran ada berbagai jenis. Menurut Sanjaya (2009), media pembelajaran dapat dikelompokkan dalam empat kelompok, yaitu: (1) media grafis (visual) diam, (2) media proyeksi, (3) media audio, dan (4) media komputer. Media pembelajaran yang sesuai dalam pembelajaran daring adalah media yang dapat merangsang belajar peserta didik, baik melalui indra pendengar (audio) maupun indra penglihatan (visual) atau disebut video yang berbentuk sofile sehingga dapat disampaikan melalui WA atau platform pendidikan, seperti googel classroom atau zoom metting. Video pembelajaran yang menarik dapat dikembangkan menggunakan komputer sehingga dapat disesuaikan dengan kebutuhan. Media berbasis komputer merupakan media yang mengoptimalkan peran komputer sebagai sarana untuk menampilkan dan merekayasa animasi, teks, gambar, Gambar, musik dan suara dalam sebuah tampilan terintegrasi sehingga paduan antarelemen tersebut dapat membantu pendidik dalam menyampaikan materi pembelajaran daring secara menarik. Media seperti itu, misalnya videoscribe yang dikembangkan melalui aplikasi Sparkol VideoScribe.

Menurut Oktavianingrum (2016), videoscribe dapat digunakan untuk penyajian informasi serta meningkatkan efektifitas pembelajaran. Videoscribe memiliki kelebihan karena videoscribe merupakan aplikasi online dan bernuansa multimedia yang dapat berupa foto, gambar, teks, musik, dan background yang dapat dipilih sesuai keinginan. Jadi, media pembelajaran videoscribe dapat dimanfaatkan sebagai salah satu alternatif untuk mengatasi hasil belajar daring yang menurun, salah satunya adalah hasil belajar daring Bahasa Indonesia. Dengan memanfaatkan media videoscribe diharapkan dapat meningkatkan pemahaman siswa terhadap materi pembelajaran sehingga berpengaruh positif terhadap hasil belajar dan tingkat ketuntasan peserta didik.

Media videoscribe dalam pembelajaran daring bahasa Indonesia ini dibuat melalui sebuah aplikasi Sparkol VideoScribe yang berfungsi membuat video dengan simulasi tangan yang sedang menggambarkan animasi. Software ini dikembangkan oleh Sparkol, salah satu perusahaan yang ada di Inggris pada tahun 2012. Untuk mendapatkan video animasi berbentuk videoscribe tersebut, pendidik harus mampu mengoprasikan aplikasi Sparkol VideoScribe. Proses pembuatan media videoscribe yang digunakan dalam pembelajaran Bahasa Indonesia diupayakan memenuhi keriteria pembuatan video animasi yang baik. Menurut Oktavianingrum (2016), beberapa kriteria yang perlu diperhatikan dalam membuat video animasi yang menarik, yaitu (1) tema yang sesuai mengenai apa yang akan disampaikan, (2) pilihan gambar dan atau animasi yang sesuai dengan tema yang akan dibawakan, (3) pemilihan warna latar belakang, (4) efek animasi yang dipakai disesuaikan dengan audience, (5) pemilihan jenis huruf, (6) content atau isi yang akan disampaikan, dan (7) durasi video disesuaikan dengan materi yang akan disampaikan.

Hasil belajar penggunaan media videoscribe sebagi salah satu alternatif dalam pembelajaran daring Bahasa Indonesia di SMKN 1 Cangkringan dapat dilihat dari hasil 
perbandingan antara rerata nilai hasil belajar kompetensi pengetahuan dan rerata hasil belajar kompetensi dasar keterampilan sebelum dan sesudah menggunakan media pembelajaran videoscribe. Perbandingan tersebut dapat dilihat pada Tabel 4 berikut.

Tabel 4. Tingkat Kenaikan Rerata Nilai Sebelum dan Sesudah Menggunakan Media Pembelajaran Videoscribe

\begin{tabular}{|l|l|l|l|l|l|l|}
\hline Kelas & $\begin{array}{l}\text { Kompetensi } \\
\text { Dasar }\end{array}$ & $\begin{array}{l}\text { Rerata } \\
\text { Nilai } \\
\text { Sebelum }\end{array}$ & $\begin{array}{l}\text { Rerata } \\
\text { Nilai } \\
\text { Setelah }\end{array}$ & $\begin{array}{l}\text { Jumlah } \\
\text { Kenaikan }\end{array}$ & $\begin{array}{l}\text { Prosentasi } \\
\text { kenaikan }\end{array}$ & $\begin{array}{l}\text { Jumlah } \\
\text { Prosentasi } \\
\text { Kenaikan }\end{array}$ \\
\hline XI APL 2 & $\begin{array}{l}\text { Pengetahua } \\
\mathrm{n}\end{array}$ & 71,77 & 78,70 & 6,84 & $9,66 \%$ & $24,42 \%$ \\
\hline $\begin{array}{l}\text { XI APHP } \\
4\end{array}$ & $\begin{array}{l}\text { Pengetahua } \\
\mathrm{n}\end{array}$ & 69,22 & 79,3 & 9,98 & $14,42 \%$ & \\
\hline XI APL 2 & $\begin{array}{l}\text { Keterampila } \\
\mathrm{n}\end{array}$ & 73,89 & 79,24 & 5,35 & $7,24 \%$ & $23,47 \%$ \\
\hline $\begin{array}{l}\text { XI APHP } \\
4\end{array}$ & $\begin{array}{l}\text { Keterampila } \\
\mathrm{n}\end{array}$ & 68,32 & 79,4 & 11,08 & $16,23 \%$ & \\
\hline
\end{tabular}

Berdasarkan tabel tersebut dapat dijelaskan bahwa hasil belajar daring Bahasa Indonesia di SMKN 1 Cangkringan sebelum menggunakan media videoscribe, yaitu (1) rerata KD pengetahuan kelas XI APL 2 dan APHP4 adalah 71,77 dan 69,22 dengan jumlah rerata nilai 70,50 dan (2) rerata KD keterampilan kelas XI APL 2 dan APHP 4 adalah 73,89 dan 68,32 dengan jumlah rerata nilai 71,11. Setelah pembelajaran daring Bahasa Indonesia menggunakan media videoscribe didapatkan hasil belajar, yaitu (1) rerata KD pengetahuan kelas XI APL 2 dan APHP4 adalah 78,70 dan 79,3 dengan jumlah rerata nilai 79 dan (2) rerata KD keterampilan kelas XI APL 2 dan APHP 4 adalah 79,24 dan 79, 40 dengan jumlah rerata nilai 79,32.

Berdasarkan data hasil belajar daring Bahasa Indonesia pada KD pengetahuan dan KD keterampilan sebelum dan sesudah pengguanan media videoscribe yang diperoleh peserta didik maka dapat diketahui prosentasi kenaikan hasil belajar daring Bahasa Indonesia sebelum dan sesudah menggunakan media videoscribe. Prosentasi kenaikan hasil belajar daring Bahasa Indonesia sebelum dan setelah menggunakan media pembelajaran, yaitu (1) prosentasi hasil belajar daring KD pengetahuan mengalami kenaikan $24,42 \%$ sedangkan (2) prosentasi hasil belajar KD keterampilan mengalami kenaikan 23,47\%.

Hasil belajar daring Bahasa Indonesia sebelum dan setelah menggunakan media videoscribe juga dapat dilihat dari prosentasi tingkat ketuntasan. Ketuntasan hasil belajar Bahasa Indonesia dilihat berdasarkan kriteria ketuntasan minimal (KKM) yang ditentukan oleh sekolah. KKM mata pelajaran Bahasa Indonesia di SMKN 1 Cangkringan adalah 75. Prosentasi tingkat ketuntasan hasil belajar daring Bahasa Indonesia sebelum dan setelah menggunakan media videoscribe juga dapat dilihat pada Tabel 5 berikut.

Tabel 5. Tingkat Ketuntasan Peserta Didik Sebelum dan Setelah Menggunakan Media Pembelajaran Videoscribe

\begin{tabular}{|l|l|c|l|c|c|c|l|}
\hline Kelas & \multirow{2}{*}{$\begin{array}{l}\text { Kompetensi } \\
\text { Dasar }\end{array}$} & \multicolumn{2}{|l|}{ Ketuntasan Sebelum } & \multicolumn{2}{|c|}{$\begin{array}{l}\text { Ketuntasan } \\
\text { Setelah }\end{array}$} & $\begin{array}{l}\text { Jumala } \\
\text { h Siswa }\end{array}$ & $\begin{array}{l}\text { Prosentasi } \\
\text { Peningkatan } \\
\text { Ketuntasan }\end{array}$ \\
\cline { 2 - 6 } & $\begin{array}{l}\text { Rerata } \\
\text { Tunta } \\
\mathrm{s}\end{array}$ & $\begin{array}{l}\text { Rerata } \\
\text { Tidak } \\
\text { Tuntas }\end{array}$ & $\begin{array}{l}\text { Tunta } \\
\text { s }\end{array}$ & $\begin{array}{l}\text { Tidak } \\
\text { Tunta } \\
\text { s }\end{array}$ & & \\
\hline XI APL2 & $\begin{array}{l}\text { Pengetahua } \\
\mathrm{n}\end{array}$ & 17,43 & 15,57 & 30 & 3 & 66 & $37,36 \%$ \\
\hline XI APHP4 & $\begin{array}{l}\text { Pengetahua } \\
\mathrm{n}\end{array}$ & 15,71 & 17,29 & 31 & 2 & \\
\hline
\end{tabular}


LANGUAGE : Jurnal Inovasi Pendidikan Bahasa dan Sastra Vol 2. No 1. Februari 2022, e-ISSN : 2807-1670 | p-ISSN : 2807-2316

\begin{tabular}{|l|l|c|c|c|c|c|c|}
\hline XI APL2 & $\begin{array}{l}\text { Keterampila } \\
\mathrm{n}\end{array}$ & 16,57 & 16,43 & 32 & 1 & 66 & $53,59 \%$ \\
\cline { 1 - 5 } XI APHP4 & $\begin{array}{l}\text { Keterampila } \\
\mathrm{n}\end{array}$ & 20,14 & 33 & 0 & \\
\hline
\end{tabular}

Berdasarkan tabel tersebut dapat dijelaskan bahwa tingkat ketuntasan hasil belajar daring peserta didik pada mata pelajaran Bahasa Indonesia di SMKN 1 Cangkringan sebelum menggunakan media videoscribe, yaitu (1) rerata jumlah peserta didik tuntas KD pengetahuan kelas XI APL 2 dan APHP4 adalah 17,42 dan 15,71 dengan jumlah 33 dan (2) rerata jumlah peserta didik tuntas KD keterampilan kelas XI APL 2 dan APHP 4 adalah 16,57 dan 12,86 dengan jumlah 29. Setelah pembelajaran daring Bahasa Indonesia menggunakan media videoscribe didapatkan jumlah peserta didik tuntas, yaitu (1) rerata jumlah peserta didik tuntas KD pengetahuan kelas XI APL 2 dan APHP4 adalah 30 dan 31 dengan jumlah 61 dan (2) rerata KD keterampilan kelas XI APL 2 dan APHP 4 adalah 32 dan 33 dengan jumlah 65.

Berdasarkan data jumlah peserta didik tuntas dalam pembelajaran daring Bahasa Indonesia pada KD pengetahuan dan KD keterampilan sebelum dan sesudah pengguanan media videoscribe maka dapat diketahui tingkat prosentasi ketuntasan belajar daring Bahasa Indonesia sebelum dan sesudah penggunaan media videoscribe. Prosentasi kenaikan ketuntasan hasil belajar daring Bahasa Indonesia sebelum dan setelah menggunakan media pembelajaran, yaitu (1) prosentasi ketuntasan belajar daring KD pengetahuan mengalami kenaikan 37,36\% dan (2) prosentase ketuntasan hasil belajar kompetensi dasar keterampilan mengalami kenaikan $53,59 \%$.

Berdasarkan Gambar 1 nilai tertinggi dan terendah hasil pembelajaran daring Bahasa Indonesia KD pengetahuan sebelum dan setelah penggunaan videoscribe juga mengalami peningkatan. Berdasarkan Gambar tersebut nilai tertinggi KD pengetahuan sebelum penggunaan media videoscribe adalah 82, sedangkan nilai tertinggi setelah menggunakan media videoscribe adalah 90 . Nilai terendah KD pengetahuan sebelum penggunaan media videoscribe adalah 35, sedangkan nilai terendah setelah penggunaan media videoscribe adalah 70. Jadi, nilai KD pengetahuan nilai tertinggi mengalami kenaikan.

Berdasarkan Gambar 2 nilai tertinggi dan terendah hasil pembelajaran daring Bahasa Indonesia KD keterampilan sebelum dan setelah penggunaan videoscribe juga mengalami peningkatan. Berdasarkan Gambar tersebut nilai tertinggi KD keterampilan sebelum penggunaan media videoscribe adalah 86 , sedangkan nilai tertinggi setelah menggunakan media videoscribe adalah 90 . Nilai terendah KD keterampilan sebelum penggunaan media videoscribe adalah 40 , sedangkan nilai terendah setelah penggunaan media videoscribe adalah 74. Jadi, nilai KD keterampilan nilai tertinggi mengalami kenaikan.

Tingkat hasil belajar dapat menunjukan kualitas pendidikan yang diperoleh peserta didik melalui proses pembelajaran. Pendidikan dikatakan berhasil apabila proses pembelajaran dapat berjalan lancar dan sesuai dengan tujuan pembelajaran yang telah direncanakan sehingga tercapai hasil belajar yang positif, baik aspek kognitif, keterampilan, maupun afektif. Peserta didik SMK diharapkan mampu bersaing di dunia usaha dunia industri (DUDI) untuk mendapatkan pekerjaan sesuai dengan jurusannya. Daya saing tersebut akan dipengaruhi oleh hasil belajar, salah satunya adalah hasil belajar Bahasa Indonesia. Dengan tingkat hasil belajar tinggi diharapkan peserta didik lulusan SMK dapat bersaing di DUDI setelah lulus.

Untuk mewujudkan hal tersebut, pendidik harus kreatif dan inovatif dalam menyampaikan pembelajaran. Salah satunya, pendidik dapat menciptakan media pembelajaran. Seperti halnya best practice yang telah dilakukan penulis di SMKN 1 Cangkringan, Sleman bahwa pemanfaatan media videoscribe dapat menjadi salah satu alternatif dalam pembelajaran Bahasa Indonesia. Pemanfaat media videoscribe dalam pembelajaran Bahasa Indonesia di SMKN 1 Cangkringan dapat meningkatkan hasil belajar dan tingkat ketuntasan peserta didik. 


\section{KESIMPULAN}

Hasil pemaparan data yang diperoleh menunjukan bahwa pemanfaatan media pembelajaran videoscribe sebagai alternatif pembelajaran daring Bahasa Indonesia kelas XI di SMKN 1 Cangkringan dapat meningkatkan hasil belajar. Hal ini ditunjukan oleh peningkatan hasil belajar KD pengetahuan sebesar $24,42 \%$, sedangkan peningkatan hasil belajar KD keterampilan sebesar 23,47\% dan peningkatan ketuntasan KD pengetahuan sebesar 37,36\%, sedangkan peningkatan ketuntasan KD keterampilan sebesar 53,59\%. Berdasarkan data tersebut terdapat peningkatan hasil belajar dan tingkat ketuntasan peserta didik.

Dengan demikian, best practice yang telah dilakukan di SMKN 1 Cangkringan, Sleman, Yogyakarta berdampak positif bagai guru dan peserta didik. Bagi peserta didik dapat meningkatkan hasil belajar, sedangkan bagi pendidik sebagai motivasi untuk dapat berinovasi dan berkreatifitas untuk memberikan pembelajaran terbaik bagi peserta didik. Inovasi dan kreatifitas yang dilakukan pendidik dapat membawa perubahan yang lebih positif.

\section{DAFTAR PUSTAKA}

Ahmad, Rivai \& Nana, Sudjana. 2013. Media Pengajaran (Penggunaan dan Pembuatannya). Bandung: Sinar Baru Algensindo.

Dimyati. 1999. Belajar dan Pembelajaran. Jakarta: Rineka Cipta.

Hasan, Muhammad, dkk. 2001. Media Pembelajaran. Jawa Tengah: Tahta Media Group.

Hudhana, Winda Dwi \& Sulaeman, Agus. 2019. Pengembangan Media Video Scribe dalam Peningkatan Kemampuan Menulis Cerpen Berbasis Karakter Siswa Kelas X SMA seKabupaten Tangerang. FKIP Universitas Jambi: Pena: Jurnal Pendidikan Bahasa dan Sastra. Vol 9, No 1 (2019). ISSN: 2615-7705.

K, R Gilang. 2020. Pelaksanaan Pembelajaran Daring di Era Covid-19. Banyumas: Penerbit Lutfi Gilang.

Matondang, Zulkifli dkk. 2019. Evaluasi Hasil Belajar. Medan: Yayasan Kita Menulis.

Octavianingrum, Dilla. 2016. "Pengembangan Media Audio Visual Sparkol Videoscribe Dalam Pembelajaran Mengelola Pertemuan/Rapat Di Lembaga Pendidikan Profesi (LPP)

IPMI Kusuma Bangsa Surakarta Jurusan Administrasi Perkantoran”

Pangondian, Roman A., Santoso, Insap P., \& Nugroho, Eko. 2019. Faktor-Faktor yang Mempengaruhi Kesuksesan Pembelajaran Daring dalam Revolusi Insudtri 4.0. Seminar Nasional Teknologi Komputer dan Sains (SAINTEKS).

Permendiknas 2016 No. 024. Lampiran 03 Materi SMK 2013: Tentang Kompetensi Inti dan Kompetensi Dasar.

Sanjaya, W. 2008. Strategi Pembelajaran Berorientasi Standar Proses Pendidikan. Jakarta: Kencana Prenada Media Group.

Sanjaya, Wina. 2010. Strategi Pembelajaran Berorientasi Standar Proses Pendidikan. Jakarta: Kencana.

Setyowati, Pipin \& Vertika, Penggayuh. 2019. Pangaruh Model Pembelajaran Discovery Learning Menggunakan Video Scribe Sparkol terhadap Hasil Belajar Siswa SMK Perwari Tulungagung Tahun Ajaran 2017/2018. STKIP PGRI Tulungagung: JOEICT (Jurnal of Education and Information Communication Technology. Vol 3, No 1, Maret 2019 12-21. ISSN: 2459-993X.

Yaumi, Muhammad. 2018. Media dan Teknologi Pembelajaran. Jakarta: Prenadamedia Grup. 